\title{
The Effects of Talent Management on Employees Performance in Oil Jam Petrochemical Complex (Oil JPC): The Mediating Role of Job Satisfaction
}

\author{
Mohim Sheihaki Tash ${ }^{1}$, Elham Nowrouzi Cheshmeh Ali $^{1} \&$ Maryam Ahmadzadeh $^{1}$ \\ ${ }^{1}$ Department of Entrepreneurship Management, Faculty of Management and Economics, University of Sistan \\ and Blauchestan, Zahedan, Iran \\ Correspondence: Maryam Ahmadzadeh, M.A in Organizational Entrepreneurship, Faculty of Management and \\ Economics, University of Sistan \& Baluchestan, Zahedan, Iran. E-mail: maryam.ahmadzadeh66@gmail.com
}

Received: March 10, 2016

Accepted: May 10, 2016

Online Published: May 25, 2016

doi:10.5539/ijef.v8n6p226

URL: http://dx.doi.org/10.5539/ijef.v8n6p226

\begin{abstract}
Talent management science uses strategic human resource planning in order to improve business value and to help firms and organizations to achieve their purposes. Efforts have been done to attract, retain, develop, reward people in order to make them a part of talent management and strategic workforce planning. Talent management not only can hire, reinforce and evaluate the talent, but also it can lead to Personal growth, satisfaction in employees'. The aim in this study is to investigate the relationship between talent management and Job satisfaction among the Oil Jam Petrochemical Complex. This is a descriptive survey research. The questionnaire with 31 questions was distributed among the Oil JPC employees'. The study adopted a descriptive research design in which the target population of 2,500 employees of Oil Jam Petrochemical Complex. The study used stratified sampling method to select 83 employees according to their job cadres. Reliability was assessed by Cronbach's Alpha 0.836 . The collected data were analyzed by Descriptive and inferential statistics in descriptive and correlations test format for analyzing the SPSS data. The findings indicated that, from audiences' perspective, there is a significant effect between factors such as attracting the talents, Alignment, talents maintenance, developing the talents and job satisfaction.
\end{abstract}

Keywords: talent management, attracting talents, alignment, employee performance, job satisfaction, Oil Jam Petrochemical Complex (Oil JPC)

\section{Introduction}

Talent Management is one of the primary management tools for managing human assets in the 21 st century, because major resources for companies to compete is not just land, capital and other physical assets and the human capital is required for organizations to adapt to global rivalry and to maximize profit related to the present technology prosperous (Cappelli, 2008).

In this century it is becoming a developing scheme and has been implemented in almost the entire firms around the world (Bhatnagar, 2008). Talent management When an organization becomes aware of its personal potential, it is much easier to improve their professional development. Since the development needs investment choices realizing learning, training process and improvement in individuals such growth, succession planning, performance management etc, it is still remains a challenge to make investment and talent decisions in order to realize these matters (Phillips, 1998).

Increase in employees' satisfaction leads to large value and benefits for organizations and their employees. In general, it can be claimed that talent management is one of the effective factors in job satisfaction which can be used as an instrument for improving the hiring process and applying high skilled and able people for conducting the organizational processes. In addition, using such a tool, we can use qualified people having the true abilities in the correct positions to achieve the goals and tactics and to create job satisfaction through the identification and optimization talents and strengthening them. Besides, it can be said that, talent management not only hires, evaluate and strengthen the talents, but also it leads to personal growth, satisfaction and value for employees. In fact it's necessary to concentrate on talent management (HajiKarimi \& Soltani, 2011). We are trying to answer this question: Is there any significant relationship between talent management and job satisfaction in Oil JPC. 


\section{Literature Review}

Talent management is an important element of business strategy in many firms (Lady, Khan, Rahman, \& August, 2011). The main objective behind the development of talent management is to improve the recruitment, selection, retention, and staff development to meet the present challenges the organizations are faced and to improve organizational performance realizing organizational needs (Bhatnagar, 2008) (Ashton \& Morton, 2005) mentioned that there is no single definition of talent management. Since acknowledgement of present arrival era of talent, it is not surprising that talent management now has become the renewed significance.

According to (INGHAM, 2006), to develop strategic proficiencies, the employers need to ensure they following the requirements for their talent management program including specific success standards used to determine the contribution of their programs. Talent management here does not apply to the entertainer's management. Talent management is the science based on strategic HR to improve business validity and make it possible for firms and organizations to achieve their purposes.

The Main Areas of Talent Management

- Attracting the talents: What kind of individuals the organization must invest on? How should we make a plan for hiring the individuals in determined positions? What kinds of talents are required for organization development? These questions are just a part of questions which must be considered in an organization at the time of hiring the employees as the most valuable organizational capital.

- Maintenance and alignment of talents: In order to ensure the organization is using its human resource in the true way, the work force performance must be managed. It's also necessary to consider the report outputs and analysis derived by assessing the talents and individuals' performance in the system of calculation the compensation of employees.

- Talents development: The final stage of this process includes the subjects Associated with learning and development. Here employees need to clear their career development path. Also, organizations need to invest more in the staffs to create learning and development opportunities so as to use them for responding the future expectations and requirements (Tajaldin \& Eghbali, 2008).

\section{Talent Management Dimensions:}

- Communications: Communications are the final concentration point. The Communication meetings are being held three times a year in order to obtain the new and updated data from employees.

- Job development: This case can be conducted twice a year in order to obtain the information about the employees' progress and also using the opportunities for growth and advancement.

- Reward and recognition: it's another variable which must be considered. It starts when the supervisors of employees recognize a specific amount of reward for conducting or completing a project.

Here the successful identification and completing the project is very important.

- Performance management: encouraging and developing the employees in order to obtain the higher performance level.

\subsection{Job Satisfaction}

Job satisfaction is one of the Employee job attitudes. In general we can say that job satisfaction is personal's attitude to job and is called sets of positive desires or positive feelings that people have toward their jobs, When we say a person has a high job satisfaction that's mean he loves his job very much And through it To satisfy his needs therefore has positive feelings (Lise et al., 2004). Knral and Smith pointed out five aspect of job. These aspects indicate the most important features of a job is related to the positive reaction of people to it. One can get satisfaction in relation to five aspects of job. These aspects include:

A) Nature of job: the properties and characteristics of job burdens there.

B) Salary: The amount of money a person gets paid and the degree how fair his salary is against to the salary of others.

C) Promotion opportunities: opportunities to improve position in the organizational hierarchy.

D) Supervision and care: how to communicate with their direct supervisor and the supervisor's ability to provide behavioral support and technical assistance.

E) Colleagues: Degrees that coworkers are technically efficient and responsible people. Obviously you cannot expect staff efficiency and productivity regardless of job satisfaction factor, especially from skilled staff in an 
organization.

\subsection{Organization and Job Satisfaction}

Job satisfaction is an important subject in employees' performance. Job satisfaction is "enjoy and positive feeling" about job which depends on the relationship between what employee expect about his/her job and what is provided for him/her. The job satisfaction is the satisfaction of an individual about his/her activities in organization and determines that, how much the individual tasks and job matches his/her spirit and talents. All employees have requirements and for fulfilling these requirements they work. When these needs are met, the individuals will be satisfied with their jobs. In the other word, if the individual's requirements are not fulfilled, he/she will think about leaving the organization.

When an employee is not satisfied with the job and doesn't quite it means that he/she doesn't have a better job opportunity. Without doubt his/her efficiency will be reduced. But if there are many better job opportunities available, the individual will leave the organization. Many of People, who are not satisfied with their jobs and don't leave the organization because of environmental situation, are not good actors for organizations. In this situation the individual is not efficient and creative for organization and he/she will leave the organization for a better situation (Nouri \& Parker, 1998).

\section{Hypothesis}

1) Attracting the talents affects the employees' job satisfaction in Oil JPC

2) Alignment, keeping the talents affects the employees' job satisfaction in Oil JPC

3) Developing the talents affects the employees' job satisfaction in Oil JPC

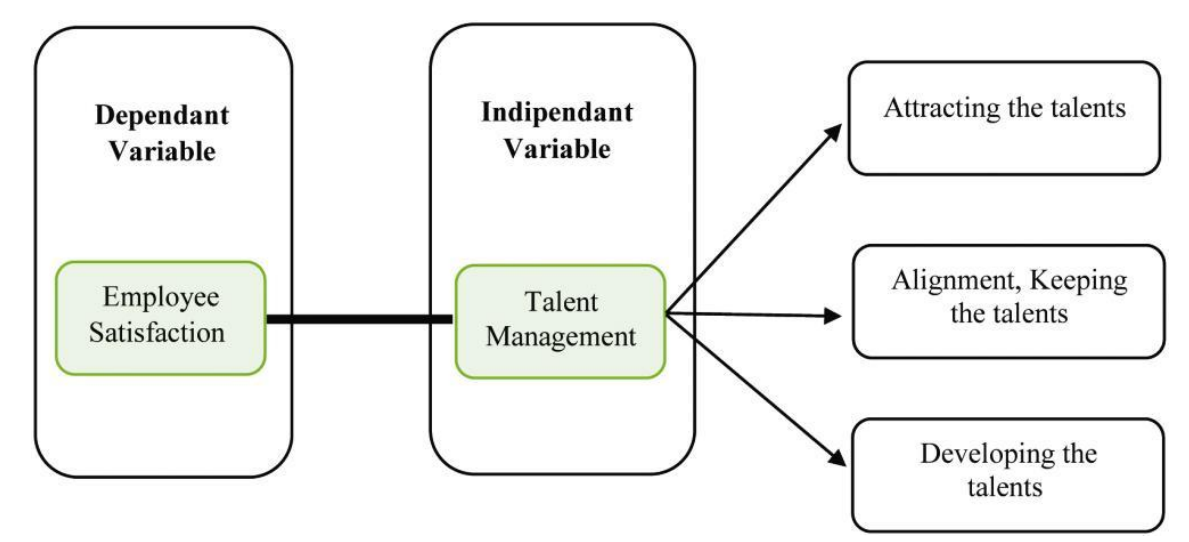

Figure 1. Conceptual model

\section{Research Methodology}

The results are in two levels of descriptive statistics (Frequency, percentage, frequency of density, and the average) and inferential statistics (based on the type of variables, the single sample t-test and ANOVA is used).

The research design which was used comprised of both qualitative and quantitative. The design consisted of questionnaires and interview guides as instruments for collecting data. The study was carried out in Oil JPC with a target population of 2500 employees used stratified sampling method to select 83 employees according to their job cadres. Data was collected using structured questionnaires both descriptive and inferential statistics were used to analyze the data. Descriptive statistics consisted of computation of sums, means, standard deviations, frequencies and percentages were used. 


\subsection{Data Analysis}

Table 1. Summery on sample demographic variable

\begin{tabular}{llll}
\hline & & Frequency & Percentage \\
\hline \multirow{3}{*}{ Education } & Diploma & 8 & 9.63 \\
& Associate Degree & 16 & 19.28 \\
Bachelor & 29 & 34.94 \\
MS & 19 & 22.9 \\
& Ph.D. & 11 & 13.25 \\
& Total & 83 & 100 \\
\hline Work preference & Less than 20 & 0 & 0 \\
& $21-30$ & 34 & 40.96 \\
& $31-40$ & 29 & 34.94 \\
& $41-50$ & 16 & 19.28 \\
& Over than 50 & 4 & 4.82 \\
& Total & 83 & 100 \\
\hline
\end{tabular}

In this investigation, the total of responses were related 83 people. 8 people had diploma (9.63\%), 16 people had Associate Degree (19.28\%), 29 people had Bachelor (34.94\%) and 19 people had MS (22.9\%) and 11 people had Ph.D. (13.25\%). Also in work preference 0 people $(0 \%)$ had less than 20 years' work experience and 34 people (40.96\%) had 21 to 30 years' work experience and 29 people (34.94\%) had 31 to 40 years' work experience and 16 people (19.28\%) had 41 to 50 years' work experience and 4 people $(4.82 \%)$ had over 50 years' work experience. Based on the above table, among 83 samples about $92 \%$ of respondents have more than 5 years of work experience hand have a good experience in research which helps to the better quality and a better response to the questionnaire.

\subsection{Inferential Research Results}

Table 2. Summery result

\begin{tabular}{llcccc}
\hline Variable & No & Correlation Coefficient & Significance Level & Confirmed hypothesis \\
\hline $\begin{array}{l}\text { Attracting the talents and job } \\
\text { satisfaction among the employees }\end{array}$ & 83 & 0.465 & 0000 & H0 is rejected and H 1 is accepted \\
alignment, keeping the talents on job & 83 & 0.636 & 0000 & H0 is rejected and H 1 is accepted \\
satisfaction & & 0.539 & 0000 & H0 is rejected and H 1 is accepted \\
$\begin{array}{l}\text { Developing the talents on job } \\
\text { satisfaction among the employees }\end{array}$ & 83 & & & & \\
\hline
\end{tabular}

\section{Conclusion}

The study of the relationship between talent management and job satisfaction among the employees Oil Jam Petrochemical Complex is evaluated. The findings indicated the positive and significant relationship between implementing the relevant policies to the manager of the Oil JPC employees with job satisfaction among the employees. According to the positive effect of talent management in satisfaction, these is factor i.e. the satisfaction are considered as the variables which have an important roles in right and appropriate implementing the policies related to talent management. Based on the findings, we can understand that, there are many companies which are working without considering the size and the industry they are involved in. they can obtain some advantages from increasing and integrating some of the policies and procedures of human resource management which are obviously relevant to attracting the talents, alignment, keeping the talents and developing the talents. Managers play a critical role in this context. Especially by considering the reasons which motivate the employees and lead them to obtain the learning opportunities; and show good behavior and respect toward their employees. Some of the companies, when they find out their employees are thinking about leaving the job, increase the income, pay reward to the employee (Dell \& Hickey, 2002). Briefly, talent management is an immediate approach for dealing with Workforce crisis and also it's an active strategy for strengthening competitive position of the company and brand. Besides, if a company wants to manage its talents in a right way, it must apply them in a right way and considers the motivating factors in order to improve the job satisfaction 
and encouraging them for fulfilling and keeping their commitments. Efficient talent management will lead to increase in employees' satisfaction which makes employees to fulfill their commitments.

According to the positive effect of talent management in job satisfaction. Based on the findings, we can understand that, there are many companies which are working without considering the size and the industry they are involved in. they can obtain some advantage from increasing and integrating some of the policies and procedures of human resource management which are obviously relevant to attracting the talents, alignment, keeping the talents and developing the talents. Managers play a critical role in this context. Especially by considering the reasons which motivate the employees and lead them to obtain the learning opportunities; and show good behavior and respect toward their employees. Some of the companies, when they find out their employees are thinking about leaving the job, increase the income, pay reward to the employee (Dell and Hickey, 2002). Briefly, talent management is an immediate approach for dealing with Workforce crisis and also it's an active strategy for strengthening competitive position of the company and brand. Besides, if a company wants to manage its talents in a right way, it must apply them in a right way and considers the motivating factors in order to improve job satisfaction and encourage them to do and keeping their commitments. Efficient talent management will lead to increase in employees' satisfaction and which makes employees to fulfill their commitments.

\section{References}

Ashton, C., \& Morton, L. (2005). Managing talent for competitive advantage: Taking a systemic approach to talent management. Strategic HR Review, 4(5), 28-31. http://dx.doi.org/10.1108/14754390580000819

Bano, S., Khan, M. A., Rehman, Q. H. U., \& Humayoun, A. A. (2011). Schematizing talent management, a core business issue. Far East Journal of Psychology and Business, 2(1), 4-16.

Bhatnagar, J. (2008). Managing capabilities for talent engagement and pipeline development. Industrial and Commercial Training, 40(1), 19-28. http://dx.doi.org/10.1108/00197850810841602

Cappelli, P. (2008). Talent management for the twenty-first century. Harvard Business Review, 86(3), 74.

Dell, D. J., \& Hickey, J. (2002). Sustaining the Talent Quest: Getting and Keeping the Best People in Volatile Times. Conference Board.

Hajikarimi, A., \& Soltani, M. (2011). Study and Analysis of Talent Management Measures: A Case Study of IRAN Machinery and Industrial Equipment Industry. Journal of Organizational Culture Management, 23(9), 95-116.

Ingham, J. (2006). Closing the talent management gap: Harnessing your employees' talent to deliver optimum business performance. Strategic HR Review, 5(3), 20-23. http://dx.doi.org/10.1108/14754390680000877

Lise, M. S., \& Timothy, A. J. (2004). Employee Attitudes and Job Satisfaction. Journal of Human Resource Managemen, 43(4), 395-407.

Nouri, H., \& Parker, R. J. (1998). The relationship between budget participation and job performance: The roles of budget adequacy and organizational commitment. Accounting, Organizations and Society, 23(5), 467-483. http://dx.doi.org/10.1016/S0361-3682(97)00036-6

Phillips, J. M. (1998). Effects of realistic job previews on multiple organizational outcomes: A meta-analysis. Academy of Management Journal, 41(6), 673-690. http://dx.doi.org/10.2307/256964

Tajaldin, M., \& Eghbali, E. (2008). Strategic thinking with an approach to entrepreneurship. The third International Conference of strategic management, p. 4.

\section{Copyrights}

Copyright for this article is retained by the author(s), with first publication rights granted to the journal.

This is an open-access article distributed under the terms and conditions of the Creative Commons Attribution license (http://creativecommons.org/licenses/by/3.0/). 